\title{
Radiochemical assay to measure the biofilm produced by coagulase-negative staphylococci on solid surfaces and its use to quantitate the effects of various antibacterial compounds on the formation of the biofilm
}

\author{
M. HUSSAIN, C. COLLINS, J. G. M. HASTINGS* and P. J. WHITE†
}

Department of Molecular Biology and Biotechnology, The University, Western Bank, Sheffield S10 2TN

\begin{abstract}
Summary. A firmly adherent mass of slime plus organisms (biofilm) accumulates on the sides of culture tubes when some strains of coagulase-negative staphylococci are grown in a chemically-defined medium containing $\left[{ }^{14} \mathrm{C}\right]$ glucose. This mass was washed (to remove labelled medium) and then counted after adding scintillation fluid. Organisms from the liquid culture were also washed and counted to check that $\left[{ }^{14} \mathrm{C}\right]$ glucose had been utilised to label the bacteria. Nine strains were examined in this way, and the results were compared with those obtained with four older techniques for recognising slime production or adherent bacteria. The new method is quick, and has advantages of reproducibility and good discrimination between strains; there was a 15 -fold difference in counts in the biofilm between slimeproducing and non-producing strains respectively. With the new radiolabel assay, the effects of several antibacterial compounds on the build-up of the biofilm were investigated with four slime-producing strains. Tunicamycin, chloramphenicol and 5-fluorouracil, at levels below their minimum growth-inhibitory concentrations, each greatly diminished biofilm formation; several other drugs had less effect.
\end{abstract}

\section{Introduction}

Coagulase-negative staphylococci (CNS), together with corynebacteria, make up a major part of the normal flora of human skin. They were previously considered to be non-pathogenic but have now emerged as important pathogens. ${ }^{1,2}$ Callaghan et al. ${ }^{3}$ first reported colonisation of Spitz Holter valves by staphylococci. Now CNS have been recognised as major causative organisms in other foreign-bodyrelated infections. CNS adhere to solid surfaces and cell division leads to formation of adherent microcolonies. Further multiplication results in the development of biofilm. ${ }^{4-9}$ During the course of colonisation of a foreign body, the organisms produce a viscous substance termed slime, which may protect the embedded bacteria from the host defence system and antibiotics. ${ }^{5,10-16}$

Growth of CNS in a chemically-defined medium containing $\left[{ }^{14} \mathrm{C}\right]$ glucose leads to heavy labelling of the extracellular polysaccharide that is a large part of the slime made by these bacteria. ${ }^{17}$ Counting the radio-

Received 19 Feb. 1991 ; accepted 10 Sept. 1991.

* Present address: Department of Clinical Microbiology, The Queen Elizabeth Hospital, Queen Elizabeth Medical Centre, Birmingham B15 2TH.

$\dagger$ Correspondence should be sent to Dr P. J. White. activity of the material (slime plus organisms) that becomes adherent to the sides of the culture vessels during growth has now been used to measure the biofilm quantitatively. This new procedure was compared with several other methods that are used to assess slime and bacteria in the biofilm. The effects of low concentrations of some growth-inhibitors on formation of biofilm were also studied.

\section{Materials and methods}

\section{Organisms}

The following isolates of Staphylococcus epidermidis were used: RP-12, RP-62A, C362, C762, C988, C1543, C1276 and A2057. Strains RP-12 (ATCC 35983) and RP-62A (ATCC 35984) were obtained from the American Type Culture Collection, Rockville, MD, USA and had been reported previously as highly adherent and good slime-producing strains. ${ }^{10,18,19}$ Strain KH11 was kindly provided by Dr G. Peters (Institute of Hygiene, University of Cologne, Germany). Strains C762, C1276, C1543 and A2057 were all isolated from infected long intravenous catheters in the Bacteriology Department, Royal Hallamshire Hospital, Sheffield; strains C362 and C988 were skin 
isolates. All strains were identified as $S$. epidermidis according to the scheme of Kloos and Schleifer ${ }^{20}$ by the API STAPH system (bioMerieux, Basingstoke). Strains RP-12, RP-62A, C762 and C1543 produced slime as detected by the tube adherence test ${ }^{10}$ and for the sake of clarity these are henceforth called "slime producers". The remaining strains KH11, C362, C988, C1276 and A2057 gave negative results in the tube test and are designated as "non-producers".

\section{Media}

The chemically-defined medium HHW ${ }^{21}$ and Tryptic Soy Broth (TSB; Difco) were used. The concentrations of (unlabelled) glucose in these media were $0.5 \% \mathrm{w} / \mathrm{v}$ (medium HHW) and $0.25 \% \mathrm{w} / \mathrm{v}$ (TSB).

\section{Detection of slime production}

Tube adherence test. Ability of the strains to produce slime was determined by the tube adherence test; ${ }^{10}$ $10 \mathrm{ml}$ of medium in a glass $30-\mathrm{ml}$ screw-capped bottle was inoculated with $0.1 \mathrm{ml}$ of overnight bacterial growth suspended in water and adjusted to an $\mathrm{OD}_{540}$ of 1.0 (to contain $c .1 \times 10^{9} \mathrm{cfu} / \mathrm{ml}$ ). After incubation at $37^{\circ} \mathrm{C}$ for $18 \mathrm{~h}$, tubes were emptied and their inner sides were stained with Alcian Blue (Sigma) 0.1\% $\mathrm{w} / \mathrm{v}$; the presence of a stained adherent layer was considered to indicate slime production.

Reaction with poly L-lysine and lectins. Bacteria were grown overnight in liquid medium HHW, washed once in phosphate-buffered saline $(\mathrm{pH} \mathrm{7.4)}$ and adjusted to an $\mathrm{OD}_{540}$ of $1.0\left(c .1 \times 10^{9} \mathrm{cfu} / \mathrm{ml}\right)$. This bacterial suspension $(20 \mu \mathrm{l})$ was mixed separately with $20 \mu \mathrm{l}$ of poly-L-lysine (specific to $\alpha$-D-glucuronic acid and L-lysine) or lectins (Concanavalin-A, specific to $\alpha$ $\mathrm{D}$-glucose or $\alpha$-D-mannose; Maclura promifera lectin, specific to $\alpha$-D-galactose or $\mathrm{N}$-acetyl $\alpha$-D-galactosamine; Pisum sativum lectin, specific to $\mathrm{N}$-acetyl $\alpha$-Dglucosamine) on a glass slide. Results were recorded after $1 \mathrm{~min}$ as - or,,++++++ , according to the extent of the clumping reaction as judged by eye.

Dye-binding assay. A modification of the method of Ramus ${ }^{22}$ was used. Alcian Blue was dissolved $(1 \mathrm{mg} / \mathrm{ml})$ in $0.5 \mathrm{M}$ acetic acid $(\mathrm{pH} \mathrm{5.2)}$ and filtered through Whatman No. 1 paper. A sample (4 ml) of an overnight liquid culture of each strain (in $10 \mathrm{ml}$ of medium HHW grown in glass 30-ml bottles with shaking; if any small quantity of biofilm was visible, it was dispersed by vortex mixing) and $1 \mathrm{ml}$ of the dye solution were mixed thoroughly and then left to stand at room temperature for $2 \mathrm{~h}$. The bacteria were removed by centrifugation $(4500 \mathrm{rpm}, 20 \mathrm{~min})$ and the absorbance of the supernate was measured at $610 \mathrm{~nm}$, with water for zero setting. The slime is believed to be a polyanion, and, as such, it complexes with the cationic dye, taking it out of solution and lowering the absorbance at $610 \mathrm{~nm}$. Therefore, the amount of slime is inversely proportional to the absorbance. The procedure was repeated for each strain, with the modification that the organisms were removed from the medium (by centrifuging as above) before the dye was added. Dye was also added to sterile uninoculated medium to establish whether the initial components of the medium removed the colour from solution.

\section{Assays of adherent bacteria}

ATP bioluminence assay. Bacterial strains were grown overnight in medium HHW or TSB, diluted 100-fold with fresh medium to contain c. $1 \times 10^{7}$ $\mathrm{cfu} / \mathrm{ml}$, and then $0.2 \mathrm{ml}$ was transferred into the wells of a polystyrene flat-bottomed microtitration plate (Amersham International plc, Aylesbury). Each strain was tested in triplicate on three separate occasions. The plate was covered and, after incubation at $37^{\circ} \mathrm{C}$ for $18 \mathrm{~h}$, wells were aspirated and washed twice with normal saline by means of an automated plate washer (Amersham International); ATP was extracted from adherent bacteria by adding $0.2 \mathrm{ml}$ of trichloroacetic acid $2.5 \% \mathrm{w} / \mathrm{v}$. A $0.01-\mathrm{ml}$ sample of this extract was then transferred to another microtitration plate containing $0.2 \mathrm{ml}$ of $0.1 \mathrm{M}$ Tris- $\mathrm{HCl}$ buffer ( $\mathrm{pH} 7.8), 4 \mathrm{~mm}-$ EDTA- $\mathrm{Na}_{2} ; 0.03 \mathrm{ml}$ of ATP monitoring reagent (LKB-Wallac, Oy, Finland, 1243-102) was added, and the light output was measured in a microtitration plate luminometer (Amerlite; Amersham International). A second reading of light output was made after the further addition of $0.01 \mathrm{ml}$ of ATP standard (LKBWallac). The following formula was used to calculate the ATP concentration:

ATP (pmol in sample) $=$ Light output from sample $(\mathrm{mV}) /$ Light output from standard $(\mathrm{mV}) \times$ Amount of standard added (pmol).

Spectrophotometric method. The method of Christensen et $a l^{23}$ was used with slight modifications. Bacterial suspensions $\left(0.2 \mathrm{ml} ; c .1 \times 10^{7} \mathrm{cfu} / \mathrm{ml}\right)$ in medium HHW or TSB were poured separately in triplicate into a polystyrene 96-well flat-bottom microtitration plate. After incubation for $18 \mathrm{~h}$ at $37^{\circ} \mathrm{C}$, wells were aspirated and washed twice with normal saline. Adherent growth was stained with safranin for $1 \mathrm{~min}$, washed with distilled water and allowed to dry. Optical density was determined at $490 \mathrm{~nm}$ in a Microelisa Minireader MR590 (Dynatech, Guernsey, Channel Islands).

\section{$\left[{ }^{14} \mathrm{C}\right]$ glucose assay for quantitation of adherent bacteria + slime}

Medium HHW ( $5 \mathrm{ml})$ containing uniformly labelled $\left[{ }^{14} \mathrm{C}\right]$-glucose $(0 \cdot 1 \mu \mathrm{Ci} / \mathrm{ml}$ of medium $)$ in a sterile plastic scintillation vial was inoculated with $0.1 \mathrm{ml}$ of an overnight bacterial culture in the same medium (not radioactive) diluted with sterile distilled water to contain c. $1 \times 10^{9} \mathrm{cfu} \mathrm{ml}$. After standing at $37^{\circ} \mathrm{C}$ for $18 \mathrm{~h}$, the medium was decanted, and the adherent bacterial layer was carefully washed twice with distilled water and then shaken vigorously in a mixture containing $1 \mathrm{ml}$ of distilled water plus $9 \mathrm{ml}$ of scin- 
tillation fluid SAFE FLUOR S (Lucam*Lsc, Olen, Belgium). Radioactivity in each vial was measured in a Beckman LS 1801 liquid scintillation counter (Beckman Instruments, Fullerton, CA, USA) either for $10 \mathrm{~min}$ or until the $2 \mathrm{SIG} \%$ value was 1.00 . The assay was done in triplicate and repeated at least three times. Results are expressed as mean and SD of triplicate readings.

Adherent counts were also measured after the organisms had been grown similarly in TSB containing $\left[{ }^{14} \mathrm{C}\right]$ glucose $(0 \cdot 1 \mu \mathrm{Ci} / \mathrm{ml}$ of medium $)$.

\section{Antibacterial agents}

Antibacterial drugs used in this study were: methicillin (Beecham Laboratories), chloramphenicol (Sigma), ciprofloxacin (Bayer), erythromycin (Abbott Laboratories), flucloxacillin (Beecham Laboratories), gentamicin (David Bull Laboratories, Warwick), imipenem (Merck, Sharp and Dohme Research Laboratories), streptomycin (Evans Medical Ltd), teicoplanin (Gruppu Leptis S. P. A., Milan), tunicamycin (Sigma), vancomycin (Eli Lilly Ltd), cefuroxime (Glaxo Laboratories Ltd) and 5-fluorouracil (Hoffmann La Roche).

Minimum inhibitory concentrations (MICs) of various drugs against different strains were determined by a dilution method (two-fold steps) in medium HHW $(5 \mathrm{ml})$; the bacterial inoculum was c. $1 \times 10^{7} \mathrm{cfu} \mathrm{ml}$. After incubation for $18 \mathrm{~h}$ at $37^{\circ} \mathrm{C}$, the first bottle without growth (obvious turbidity) was considered to contain the MIC.

Effect of 0.5 MIC on biofilm formation. Medium $(10 \mathrm{ml})$ in scintillation vials containing $\left[{ }^{14} \mathrm{C}\right]$ glucose $(1 \mu \mathrm{Ci})$ and the $\mathrm{MIC}$ or $0.5 \mathrm{MIC}$ of various agents was inoculated with overnight growth in the same medium, without agents, to contain initially $c .1 \times 10^{7} \mathrm{cfu} / \mathrm{ml}$. After incubation as static cultures for $24 \mathrm{~h}$ at $37^{\circ} \mathrm{C}$, the washing and counting of the biofilm were done as described above.

Effect of antibiotics on extracellular slime production. Medium HHW containing $\left[{ }^{14} \mathrm{C}\right]$ glucose $(100 \mu \mathrm{Ci} / \mathrm{L})$ was used. Medium (50 ml in 250-ml flasks) containing $0.5 \mathrm{MIC}$ of different antibacterial agents in separate flasks was inoculated with diluted overnight growth of strain RP-62A to give initially $c .1 \times 10^{6} \mathrm{cfu} / \mathrm{ml}$, then incubated with shaking for $24 \mathrm{~h}$ at $37^{\circ} \mathrm{C}$ in a water bath. Under these conditions of growth, very little biofilm is formed even when antibiotics are present. The bacteria + slime mixture was sonicated $(8 \mu \mathrm{m}$ amplitude for $1 \mathrm{~min}$ ), which removed all visible biofilm from the sides of the vessel, then the bacteria were removed by centrifugation. The supernatant liquid was loaded on a column of Sephadex G-50 $(3 \times 65 \mathrm{~cm})$ equilibrated with distilled water. The column was eluted with water and fractions (200 drops, c. $10 \mathrm{ml})$ were collected in a Retriever II fraction collector (Isco Inc, USA). Part $(0.5 \mathrm{ml})$ of each fraction was transferred to a scintillation vial to which $4.5 \mathrm{ml}$ of scintillation fluid was added; vials were shaken until a clear, homogeneous liquid was produced and radioactivity was measured as before. Fractions representing a peak near the void volume were pooled and their total radioactivity was taken as an indication of the total amount of high mol.-wt material.

\section{Results}

\section{Slime production}

The results of four techniques for assessing the ability of CNS to adhere to a surface or to form slime are compared in tables I and II. The tube test is qualitative, and there was difficulty in differentiating between a weakly positive slime-producing strain and a non-producing strain. The spectrophotometric method measures the adherent mass at the bottom of wells only, and not material on the walls; hence, results were not always in accordance with those of the tube test (e.g., strain C762 in table II). The difference between a weak slime-producer and a non-producer was at least seven-fold. By the ATP assay, the difference between a high slime producer and a nonproducer was only three-fold. Our new radiochemical method recognised as slime-producers exactly the same strains that were identified by the three other methods. Results in tables I and II also suggest that the quantity of slime produced varies with the medium. With all three quantitative methods, slime-producing strains invariably produced a larger adherent layer in medium HHW than in TSB and the differences between slime producers and non-producers were more distinct.

In the radiochemical tests, all nine strains produced very similar turbidities in the fluid part of medium HHW after overnight incubation. With every strain, very little glucose (measured enzymically by glucose oxidase/peroxidase assay ${ }^{24}$ ) remained in the liquid medium after overnight growth. Washed organisms (from the liquid medium) of every strain were suspended in buffer to the same optical density, and the radioactivity in equal volumes of these suspensions was counted. The counts did not vary greatly; they ranged from a maximum of $2700 \mathrm{dpm}$ (strain RP-62A) to a minimum of $1500 \mathrm{dpm}$ (strain C762), and there was no relationship between counts of the washed organisms and the counts of adherent bacteria plus slime-strain A2057 gave $2400 \mathrm{dpm}$ but was not adherent, whereas strain RP-12 gave $2000 \mathrm{dpm}$ and was very adherent.

Accumulation of adherent slime continued when incubation was continued beyond $24 \mathrm{~h}$ (fig. 1). Although the glucose had disappeared (enzymic assay) after $24 \mathrm{~h}$, most of the radioactivity was still present, as low mol.-wt material, in the medium. Presumably, in the later stages of incubation the organisms utilised some of these radioactive materials for the continuing production of biofilm. 
Table I. Comparison of four methods of assessing adhesion of CNS grown in medium HHW

\begin{tabular}{|c|c|c|c|c|}
\hline \multirow[b]{2}{*}{$\begin{array}{l}\text { Strain } \\
\text { no. }\end{array}$} & \multirow[b]{2}{*}{$\begin{array}{c}\text { Tube } \\
\text { test } \\
\text { for slime } \\
\text { production* }\end{array}$} & \multicolumn{3}{|c|}{$\begin{array}{c}\text { Mean (SD) values }(\mathrm{n}=3) \text { in assays for attached } \\
\text { biomass }\end{array}$} \\
\hline & & $\begin{array}{l}\text { Spectrophotometric } \\
\text { assay }\left(\mathrm{OD}_{610}\right)\end{array}$ & $\begin{array}{l}\text { ATP assay } \\
\text { (pmol) }\end{array}$ & $\begin{array}{c}{\left[{ }^{14} \text { C]glucose }\right.} \\
\text { assay } \\
\left(10^{4} \mathrm{dpm}\right)\end{array}$ \\
\hline RP-62A & +++ & $1.80(0 \cdot 20)$ & $69(4)$ & $4 \cdot 30(0 \cdot 15)$ \\
\hline RP-12 & $++1+++$ & $0.50(0.10)$ & $50(4)$ & $3.00(0.03)$ \\
\hline C762 & ++ & $0.30(0.07)$ & $32(6)$ & $1.20(0.02)$ \\
\hline $\mathrm{C} 1543$ & + & $0.30(0.10)$ & $38(6)$ & $1.20(0 \cdot 17)$ \\
\hline $\mathrm{C} 362$ & - & $0.05(0.01)$ & $18(1)$ & $0.55(0.05)$ \\
\hline C988 & - & $0.05(0.01)$ & $20(2)$ & $0.30(0.01)$ \\
\hline $\mathrm{C} 1276$ & - & $0.06(0.03)$ & $21(6)$ & $0.48(0.04)$ \\
\hline A2057 & - & $0.07(0.02)$ & $17(8)$ & $0.31(0.08)$ \\
\hline KH11 & - & $0.03(0.02)$ & $16(3)$ & $0.27(0.01)$ \\
\hline
\end{tabular}

*_, No slime; +-+++ , increasing intensity of colour and thickness of adherent biomass.

Table II. Comparison of four methods of assessing adhesion of CNS grown in tryptic soy broth

\begin{tabular}{|c|c|c|c|c|}
\hline \multirow[b]{2}{*}{$\begin{array}{l}\text { Strain } \\
\text { no. }\end{array}$} & \multirow[b]{2}{*}{$\begin{array}{c}\text { Tube } \\
\text { test } \\
\text { for slime } \\
\text { production* }\end{array}$} & \multicolumn{3}{|c|}{$\begin{array}{c}\text { Mean (SD) values }(n=3) \text { in assays for attached } \\
\text { biomass }\end{array}$} \\
\hline & & $\begin{array}{l}\text { Spectrophotometric } \\
\text { assay }\left(\mathrm{OD}_{610}\right)\end{array}$ & $\begin{array}{l}\text { ATP assay } \\
\text { (pmol) }\end{array}$ & $\begin{array}{c}{\left[{ }^{14} \mathrm{C}\right] \text { glucose }} \\
\text { assay } \\
\left(10^{4} \mathrm{dpm}\right)\end{array}$ \\
\hline RP-62A & +++ & $1 \cdot 10(0 \cdot 10)$ & $51(4)$ & $3 \cdot 10(0.08)$ \\
\hline RP-12 & ++ & $0.30(0.10)$ & $32(3)$ & $2.50(0.20)$ \\
\hline C762 & ++ & $0.10(0.07)$ & $19(5)$ & $1 \cdot 10(0 \cdot 11)$ \\
\hline $\mathrm{C} 1543$ & + & $0.30(0.10)$ & $22(5)$ & $0.72(0.12)$ \\
\hline $\mathrm{C} 362$ & - & $0.14(0.08)$ & $17(1)$ & $0.22(0.01)$ \\
\hline C988 & - & $0.06(0.02)$ & $17(7)$ & $0.27(0.03)$ \\
\hline $\mathrm{C} 1276$ & - & $0.05(0.02)$ & $21(6)$ & $0.49(0.04)$ \\
\hline A2057 & - & $0.10(0.04)$ & $23(2)$ & $0.43(0.17)$ \\
\hline KHII & - & $0.06(0.08)$ & $24(7)$ & $0.24(0.01)$ \\
\hline
\end{tabular}

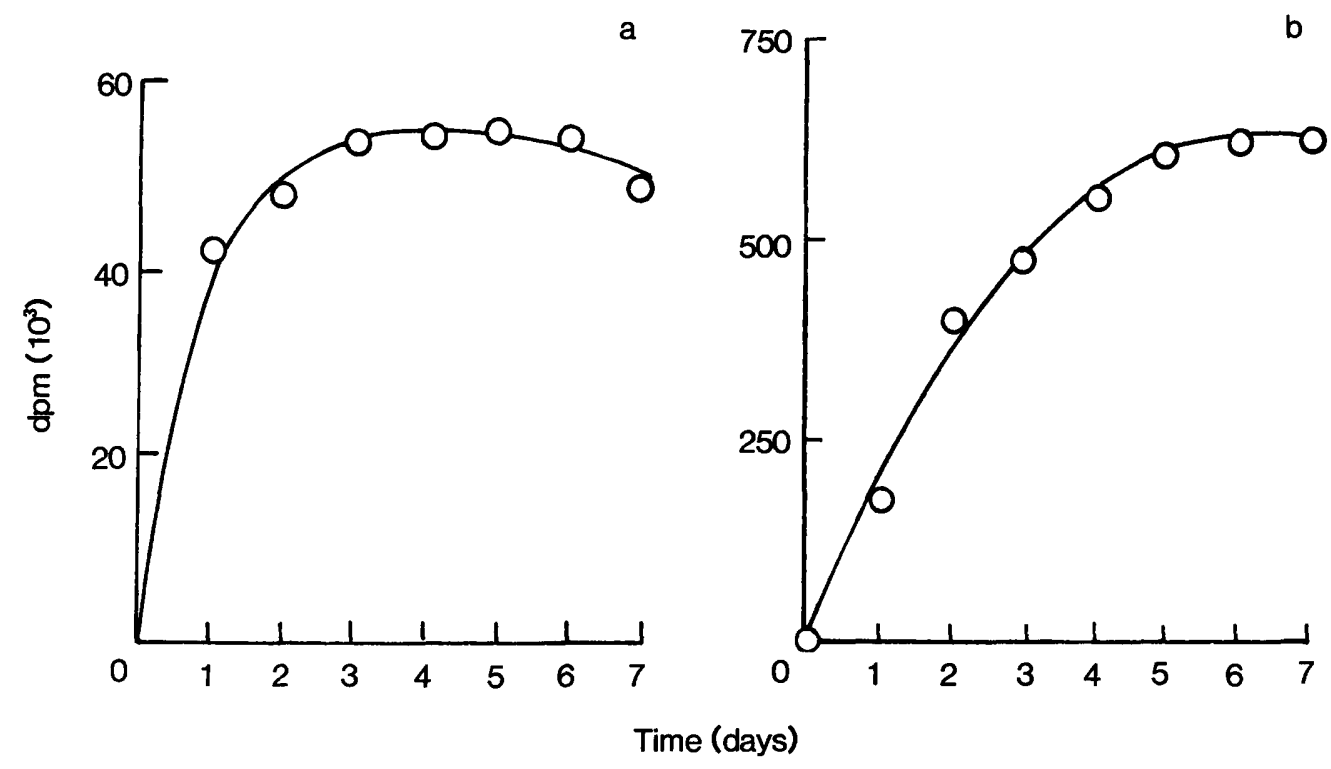

Fig. 1. (a) Accumulation of adherent radioactivity during growth of $S$. epidermidis strain RP-62A at $37^{\circ} \mathrm{C}$ in medium HHW containing $\left[{ }^{14} \mathrm{C}\right]$ glucose. (b) Formation of high mol.-wt slime during the growth of $S$. epidermidis strain RP-62A at $37^{\circ} \mathrm{C}$ in medium HHW containing $\left[{ }^{14} \mathrm{C}\right]$ glucose after various times. High mol.-wt slime was isolated on Sephadex G-50 from the supernate after removing bacteria by centrifugation. The total radioactivity in this material was measured. 
Table III. Quantitative removal of Alcian Blue by slime substance after growth in medium HHW

\begin{tabular}{l|cc}
\hline & \multicolumn{2}{|c}{$\begin{array}{c}\text { Mean (SD) percentage* }(\mathrm{n}=3) \text { of Alcian Blue } \\
\text { complexed in }\end{array}$} \\
\cline { 2 - 3 } $\begin{array}{l}\text { Strain } \\
\text { no. }\end{array}$ & $\begin{array}{c}\text { medium plus } \\
\text { organisms }\end{array}$ & $\begin{array}{c}\text { medium without } \\
\text { organisms }\end{array}$ \\
\hline RP-62A & $85(12)$ & $60(4)$ \\
RP-12 & $50(6)$ & $38(3)$ \\
C1543 & $57(5)$ & $36(4)$ \\
C762 & $61(8)$ & $44(5)$ \\
A2057 & $34(5)$ & $27(3)$ \\
C988 & 0 & 0 \\
C362 & 0 & 0 \\
C1276 & $56(7)$ & $32(5)$ \\
KH11 & 0 & 0 \\
\end{tabular}

* Percentage complexed $=[$ (absorbance of control - absorbance of test)/absorbance of control] $\times 100$; control is dye plus uninoculated medium.

\section{Reaction with poly-L-lysine and lectins}

All nine strains grown in medium $\mathrm{HHW}$ or in TSB, and uninoculated TSB (control), gave positive reactions with poly-L-lysine and Concanavalin A. As shown in tables I and II, some of these strains were not identified as slime producers by four other methods. Two highly adherent strains (RP-62A and RP12) gave a negative reaction with Pisum sativum lectin (specific for N-acetyl glucosamine) but all the other strains, whether weak slime producers or non-producers, gave positive reactions. One strain, $\mathrm{C} 1543$, gave a weak positive reaction with the lectin specific for Dgalactose.

\section{Removal of Alcian Blue by slime}

All four slime-producing strains bound a significant amount of Alcian Blue, particularly strain RP-62A. Of the five non-producing strains, three gave negative results in this test but two strains, A2057 and C1276, bound Alcian Blue equally as well as the slime producers (table III). TSB could not be used in this method because the dye was precipitated when it was added to the uninoculated medium.

Table IV. Effect of sub-inhibitory concentrations ( $0.5 \mathrm{MIC})$ of antibacterial compounds on slime production by four strains of CNS in medium HHW.

\begin{tabular}{|c|c|c|c|c|c|c|c|c|c|c|c|c|c|c|c|c|}
\hline \multirow[b]{2}{*}{ Compound } & \multicolumn{4}{|c|}{$\begin{array}{c}\mathrm{MIC}^{*} \\
(\mu \mathrm{g} / \mathrm{ml})\end{array}$} & \multicolumn{4}{|c|}{$\begin{array}{l}\text { Tube test } \\
\text { for slime production }\end{array}$} & \multicolumn{4}{|c|}{$\begin{array}{c}\text { Mean (SD) dpm } \times 10^{4} \\
\text { in }\left[{ }^{14} \mathrm{C}\right] \text { assay }\end{array}$} & \multicolumn{4}{|c|}{$\begin{array}{l}\text { Biofilm } \\
\text { formation } \dagger\end{array}$} \\
\hline & 1 & 2 & 3 & 4 & 1 & 2 & 3 & 4 & 1 & 2 & 3 & 4 & 1 & 2 & 3 & 4 \\
\hline Control & & & & & + & + & + & + & $\begin{array}{c}3.99 \\
(0.09)\end{array}$ & $\begin{array}{c}2 \cdot 41 \\
(0 \cdot 12)\end{array}$ & $\begin{array}{c}2 \cdot 12 \\
(0 \cdot 32)\end{array}$ & $\begin{array}{c}2 \cdot 31 \\
(0.09)\end{array}$ & 100 & 100 & 100 & 100 \\
\hline Cefuroxime & 32 & 16 & $0 \cdot 5$ & 2 & + & - & + & - & $\begin{array}{l}1.58 \\
(0.07)\end{array}$ & $\begin{array}{c}0 \cdot 21 \\
(0 \cdot 09)\end{array}$ & $\begin{array}{l}2 \cdot 35 \\
(0 \cdot 23)\end{array}$ & $\begin{array}{c}0.56 \\
(0.08)\end{array}$ & 40 & 9 & 110 & 24 \\
\hline Chloramphenicol & 8 & 32 & 8 & 8 & - & - & - & - & $\begin{array}{c}1.19 \\
(0.21)\end{array}$ & $\begin{array}{c}1 \cdot 77 \\
(0 \cdot 10)\end{array}$ & $\begin{array}{c}0.92 \\
(0.21)\end{array}$ & $\begin{array}{c}1.33 \\
(0 \cdot 12)\end{array}$ & 30 & 73 & 40 & 62 \\
\hline Ciprofloxacin & 0.5 & 0.5 & 0.2 & 0.5 & + & + & + & + & $\begin{array}{c}4 \cdot 19 \\
(0 \cdot 26)\end{array}$ & $\begin{array}{c}2 \cdot 12 \\
(0 \cdot 20)\end{array}$ & $\begin{array}{c}2 \cdot 53 \\
(0 \cdot 26)\end{array}$ & $\begin{array}{c}2 \cdot 19 \\
(0 \cdot 21)\end{array}$ & 105 & 88 & 119 & 95 \\
\hline Erythromycin & 128 & 64 & 128 & $0 \cdot 5$ & + & - & - & + & $\begin{array}{c}4 \cdot 39 \\
(0 \cdot 31)\end{array}$ & $\begin{array}{c}0.58 \\
(0.02)\end{array}$ & $\begin{array}{c}0.20 \\
(0.09)\end{array}$ & $\begin{array}{l}1 \cdot 21 \\
(0 \cdot 10)\end{array}$ & 110 & 24 & 9 & 52 \\
\hline 5-Fluorouracil & 1 & 0.5 & 1 & 8 & - & - & + & - & $\begin{array}{c}0.15 \\
(0.05)\end{array}$ & $\begin{array}{c}1 \cdot 12 \\
(0.09)\end{array}$ & $\begin{array}{c}1 \cdot 12 \\
(0 \cdot 12)\end{array}$ & $\begin{array}{c}0.32 \\
(0.01)\end{array}$ & 4 & 46 & 53 & 14 \\
\hline Flucloxacillin & 2 & 4 & $0 \cdot 5$ & 0.5 & + & - & - & + & $\begin{array}{c}3 \cdot 56 \\
(0 \cdot 21)\end{array}$ & $\begin{array}{c}0 \cdot 10 \\
(0 \cdot 02)\end{array}$ & $\begin{array}{c}0.98 \\
(0.09)\end{array}$ & $\begin{array}{c}1.98 \\
(0 \cdot 13)\end{array}$ & 89 & 5 & 46 & 86 \\
\hline Gentamicin & 32 & 64 & 2 & 4 & + & + & + & + & $\begin{array}{c}3 \cdot 30 \\
(0 \cdot 13)\end{array}$ & $\begin{array}{l}3.08 \\
(0 \cdot 17)\end{array}$ & $\begin{array}{l}1.87 \\
(0 \cdot 21)\end{array}$ & $\begin{array}{l}1 \cdot 18 \\
(0 \cdot 10)\end{array}$ & 85 & 127 & 88 & 51 \\
\hline Imipenem & 32 & 8 & 0.5 & 0.5 & + & - & - & - & $\begin{array}{c}2.55 \\
(0.09)\end{array}$ & $\begin{array}{c}0.11 \\
(0 \cdot 07)\end{array}$ & $\begin{array}{c}0 \cdot 72 \\
(0 \cdot 12)\end{array}$ & $\begin{array}{c}0.91 \\
(0.07)\end{array}$ & 64 & 5 & 34 & 39 \\
\hline Methicillin & 16 & 128 & 0.5 & 2 & - & - & + & + & $\begin{array}{c}0.97 \\
(0.07)\end{array}$ & $\begin{array}{c}0.89 \\
(0.03)\end{array}$ & $\begin{array}{c}2 \cdot 88 \\
(0 \cdot 31)\end{array}$ & $\begin{array}{c}3 \cdot 35 \\
(0 \cdot 21)\end{array}$ & 25 & 4 & 135 & 145 \\
\hline Penicillin & 16 & 128 & 128 & 128 & + & - & + & + & $\begin{array}{l}2 \cdot 30 \\
(0 \cdot 11)\end{array}$ & $\begin{array}{c}0.51 \\
(0 \cdot 07)\end{array}$ & $\begin{array}{c}1 \cdot 12 \\
(0 \cdot 26)\end{array}$ & $\begin{array}{l}2 \cdot 21 \\
(0 \cdot 14)\end{array}$ & 58 & 21 & 53 & 96 \\
\hline Streptomycin & 128 & 16 & 1 & 1 & + & + & + & + & $\begin{array}{c}3 \cdot 78 \\
(0 \cdot 14)\end{array}$ & $\begin{array}{c}3 \cdot 72 \\
(0 \cdot 23)\end{array}$ & $\begin{array}{c}1 \cdot 66 \\
(0 \cdot 21)\end{array}$ & $\begin{array}{c}1.87 \\
(0.06)\end{array}$ & 95 & 154 & 78 & 81 \\
\hline Teicoplanin & 4 & 8 & 8 & 4 & + & + & + & + & $\begin{array}{c}4 \cdot 37 \\
(0 \cdot 19)\end{array}$ & $\begin{array}{c}3.09 \\
(0.21)\end{array}$ & $\begin{array}{c}3 \cdot 24 \\
(0 \cdot 34)\end{array}$ & $\begin{array}{c}3.78 \\
(0.25)\end{array}$ & 110 & 128 & 153 & 163 \\
\hline Tunicamycin & 32 & 16 & 4 & 8 & - & - & - & - & $\begin{array}{c}0.50 \\
(0.06)\end{array}$ & $\begin{array}{c}0.90 \\
(0 \cdot 07)\end{array}$ & $\begin{array}{c}0 \cdot 43 \\
(0 \cdot 12)\end{array}$ & $\begin{array}{c}0 \cdot 23 \\
(0 \cdot 06)\end{array}$ & 2 & 4 & 20 & 10 \\
\hline Vancomycin & 2 & 8 & 8 & 4 & + & + & + & + & $\begin{array}{c}2 \cdot 78 \\
(0 \cdot 13)\end{array}$ & $\begin{array}{c}2.47 \\
(0 \cdot 11)\end{array}$ & $\begin{array}{c}2.97 \\
(0 \cdot 29)\end{array}$ & $\begin{array}{c}3.07 \\
(0.12)\end{array}$ & 70 & 102 & 140 & 133 \\
\hline
\end{tabular}




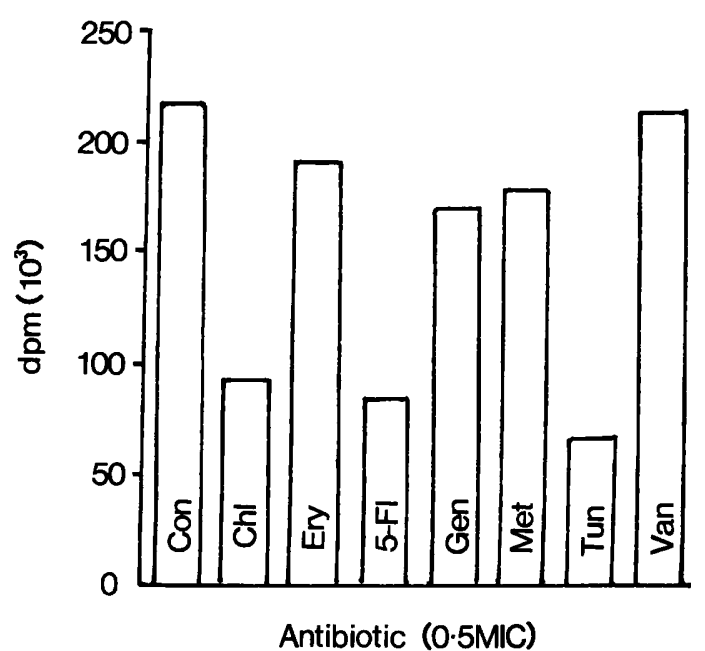

Fig. 2. Formation of extracellular high mol.-wt material (slime) by $S$. epidermidis strain RP-62A grown in the presence of $0.5 \mathrm{MIC}$ of different antibacterial compounds in medium HHW (100 ml containing $10 \mu \mathrm{Ci}$ of $\left[{ }^{14} \mathrm{C}\right]$ glucose) at $37^{\circ} \mathrm{C}$ for $48 \mathrm{~h}$.

\section{Effects of antibacterial compounds on biofilm formation and slime production}

Clues to the biochemical processes involved in biofilm production might be gained by finding specific inhibitors of this process that are effective at concentrations that do not prevent growth of the bacteria (table IV). A range of anti-bacterial drugs (mainly ones that are currently used in antibacterial chemotherapy) was tested, including specific inhibitors of protein synthesis (e.g., chloramphenicol) or of peptidoglycan formation (e.g., penicillin) as well as some compounds of less precisely defined single actions (e.g., 5-fluorouracil). Several of the drugs had little effect with any strain (ciprofloxacin, gentamicin, streptomycin, teicoplanin, vancomycin), whereas tunicamycin and chloramphenicol inhibited biofilm production by all strains. The remaining drugs had varying effects with the different strains. It was noteworthy that, in several cases, the four test strains showed widely different sensitivities (MIC values) to the same drug, e.g., MIC values for flucloxacillin ranged from 0.5 to $4 \mu \mathrm{g} / \mathrm{ml}$. This meant that when a given drug was examined for its effect on biofilm formation, the concentration at which it was used ( $0.5 \mathrm{MIC}$ ) was not necessarily the same (in terms of $\mu \mathrm{g} / \mathrm{ml}$ ) for all the test strains. In such circumstances, failure of a drug to inhibit biofilm production at $0.5 \mathrm{MIC}$ becomes difficult to interpret, because a drug, which may indeed be inhibitory when present with one strain at a relatively high concentration, might not show an effect on biofilm production at a lower concentration against a different strain. A definite inhibition of biofilm formation by a drug at $0.5 \mathrm{MIC}$ is a much less equivocal observation.

As well as inhibiting biofilm formation, chloramphenicol and tunicamycin also had effects on the amounts of high mol.-wt extracellular material isolated from the culture supernates of strain RP-62A (fig. 2).
Therefore, effects of neither drug on biofilm production can be due solely to interference with the initial attachment of the bacteria to a surface.

\section{Discussion}

The slime that is adherent to the sides of the culture tube after growth of some strains of CNS is a mixture of extracellular matrix and organisms embedded in it (biofilm). ${ }^{4-9}$ An important objective is to be able to distinguish between strains that form relatively large quantities of biofilm (slime-producers) and those strains that make relatively little (slime non-producers). Methods used to recognise slime producers may be subjective ${ }^{10,25,26}$ or quantitative. ${ }^{23,27-29}$ Unfortunately, these latter procedures do not all measure the same thing: the ATP assay ${ }^{26}$ measured only attached bacteria, and did not assess the slime; the dye-binding assay or the reaction with lectins ${ }^{25,26}$ measured the slime alone; our radiochemical assay counted total biofilm (slime plus organisms), but disregarded slime that was not adherent to the culture vessel. For these reasons, it is impossible to make exact comparison of the quantitative techniques, and a further problem is that the various investigators have studied adhesion to surfaces of different kinds-glass or plastics of several types.

Consequently, we can claim no more than that our new method of labelling with radioactive glucose is as good, or better than, other ways of recognising slime producers, and that our method has the advantage, over some techniques, of being an assessment of the total adherent biomass (biofilm). Preparation of the chemically-defined medium is time-consuming and relatively expensive, and with the strains that we have tested, TSB can satisfactorily replace medium HHW for the simple measurement of adherent biomass. However, the defined medium has great advantage in the isolation of slime, ${ }^{17,30}$ and when studying the action of inhibitors it is important to know the precise composition of the medium so as to be aware of the presence (or absence) of nutrients that might change the effects of some antimetabolites, such as 5-fluorouracil, the potency of which is affected by the concentration of uracil and thymidine.

It is important to check with new strains that the radioactive glucose is metabolised and does label the bacteria. If the extracellular material were not labelled also, our method would underestimate the total attached biomass, and might measure only the organisms. However, in every case that we have examined, the high mol.-wt carbohydrate, which is a large part of the slime, did become heavily labelled when $\left[{ }^{14} \mathrm{C}\right]-$ glucose was present in the medium. ${ }^{17}$

While our work was in progress, Van Pett et al. ${ }^{31}$ described the use of $\left[{ }^{3} \mathrm{H}\right]$ thymidine and $\left[{ }^{14} \mathrm{C}\right]$ glucose together (in TSB) to label the organisms and the extracellular slime, respectively. Two strains were examined, and the ratio of ${ }^{3} \mathrm{H}:{ }^{14} \mathrm{C}$ (low for the slime- 
producer; high for the non-producer) in the attached material was distinctive. The concentrations and specific activities of the two radioactive substrates were not given, ${ }^{31}$ so that their results (with glucose) cannot be compared with our results.

Formation of biofilm is the result of an initial attachment of the organism to a surface, followed by an increase of the adherent population and its extracellular polymers (slime). Inhibition of biofilm production, when planktonic growth can continue, seems likely to be caused by interference with primary attachment or with synthesis of the slime. The inhibition of biofilm formation that was found with tunicamycin was not unexpected, because this antibiotic interferes with the synthesis of teichoic acids, ${ }^{32}$ which represents a large part of the extracellular material made by CNS. ${ }^{17}$ Some other compounds that inhibit peptidoglycan synthesis (e.g., methicillin) might perhaps damage the bacterial wall in such a way that teichoic acid is not made properly. The inhibition by 5 -fluorouracil was surprising, as this compound is believed to act chiefly in the area of nucleic acid

\section{References}

1. Brandt L, Swahn B. Subacute bacterial endocarditis due to coagulase-negative Staphylococcus albus. Acta Med Scand 1960; 166: 125-132.

2. Pulverer G, Pillich J. Pathogenic significance of coagulasenegative staphylococci. In: Finland $M$, Margret $W$, Bartmann $K$ (eds) Bacterial infections: change in their causative agents, trend and possible basis. Bayer Symposium No. 3. Berlin, Springer Verlag. 1971: 91-96.

3. Callaghan RP, Cohen SJ, Stewart GT. Septicemia due to colonization of Spitz-Holter valves by staphylococci. Five cases treated with methicillin. $B M J 1961 ; 1: 860-863$.

4. Peters G, Locci R, Pulverer G. Microbial colonization of prosthetic devices. II. Scanning electron microscopy of naturally infected intravenous catheters. Zentralbl Bakteriol Mikrobiol Hyg 1 Abt Orig B 1981; 173: 293-299.

5. Costerton JW, Marrie TT. The mode of bacterial growth on metal and plastic prosthesis that become foci of bacterial infections. Annual Meeting of the American Society for Microbiology, New Orleans. 1983. Abstract Nó. B183.

6. Mayberry-Carson KJ, Tober-Meyer B, Smith JK, Lambe DW, Costerton JW. Bacterial adherence and glycocalyx formation in osteomyelitis experimentally induced with Staphylococcus aureus. Infect Immun 1984; 43: 825-833.

7. Costerton JW, Nickel JC, Marrie TJ. The role of bacterial glycocalyx and of the biofilm mode of growth in bacterial pathogenesis. Roche Sem Bact 1985; 2: 1-25.

8. Costerton JW, Cheng K-J, Geesey GG et al. Bacterial biofilms in nature and disease. Annu Rev Microbiol 1987; 41: 435-464.

9. Khoury T, Costerton JW. Biofilms in nature and medicine. In : Phillip KP, Fleer A (eds) 3rd ECC Symposium on foreign body-related infections. Amsterdam, Excerpta Medica. 1987: 2-15.

10. Christensen GD, Simpson WA, Bisno AL, Beachey EH. Adherence of slime-producing strains of Staphylococcus epidermidis to smooth surfaces. Infect Immun 1982; 37: 318-326.

11. Peters G, Locci R, Pulverer G. Adherence and growth of coagulase-negative staphylococci on surfaces of intravascular catheters. $J$ Infect Dis 1982; 146: 479-482.

12. Younger JJ, Christensen GD, Bartley DL, Simmons JCH, Barrett FF. Coagulase-negative staphylococci isolated from cerebrospinal fluid shunts: importance of slime production, species identification, and shunt removal to clinical outcome. J Infect Dis 1987; 156: 548-554. biosynthesis. A possible reason for its effect on biofilm formation might be the production of fluorinated derivatives ${ }^{33}$ of the UDP-sugars that are precursors of teichoic acids. Chloramphenicol is a very specific inhibitor of protein synthesis in bacteria; its effect of decreasing biofilm formation suggests that the extracellular protein made by the slime producers might be important in initial attachment, because these proteins are only a minor part of the total extracellular polymers. ${ }^{17}$ The lack of an extracellular protein that is necessary for adherence might explain why some strains are non-adherent even though they form extracellular acidic material (presumably teichoic acid) that precipitates Alcian Blue.

Further work is needed to determine the lowest concentrations of the various inhibitors that are effective, and to explore whether other inhibitors of bacterial protein synthesis disrupt biofilm formation.

M.H. was supported by a scholarship from the Government of Pakistan. We thank Dr M. Wilcox for providing antibacterial compounds used in this study.

13. Diaz-Mitoma F, Harding GKM, Hoban DJ, Robers RS, Low DE. Clinical significance of a test for slime production in ventriculoperitoneal shunt infection caused by coagulasenegative staphylococci. $J$ Infect Dis $1987 ; 156$ : 555-560.

14. Sugarman B, Young EJ (eds). Infections associated with prosthetic devices. Boca Raton, CRC Press. 1984.

15. Pulverer G. On the pathogenicity of coagulase-negative staphylococci: In: Jeljaszewicz J (ed) The staphylococci. Stuttgart, Gustav Fischer Verlag. 1985: 1-9.

16. Peters G. Staphylococcal plastic foreign body infectionsevidence and pathogenesis. In: Jeljaszewicz $J$ (ed) The staphylococci. Stuttgart, Gustav Fischer Verlag. 1985: 515-524.

17. Hussain M, Hastings JGM, White PJ. Isolation and composition of the extracellular slime made by coagulasenegative staphylococci in a chemically-defined medium. $J$ Infect Dis 1991; 163: 534-541.

18. Christensen GD, Simpson WA, Bisno AL, Beachey EH. Experimental foreign body infections in mice challenged with slime-producing Staphylococcus epidermidis. Infect Immun 1983; 40: 407-410.

19. Christensen GD, Bisno AL, Parisi JT, McLaughlin B, Hester MG, Luther RW. Nosocomial septicemia due to multiply antibiotic-resistant Staphylococcus epidermidis. Ann Intern Med 1982; 96: 1-10.

20. Kloos WE, Schleifer KH. Simplified scheme for routine identification of human Staphylococcus species. J Clin Microbiol 1975; 1 : 82-88.

21. Hussain M, Hastings JGM, White PJ. A chemically defined medium for slime production by coagulase-negative staphylococci. J Med Microbiol 1991; 34: 143-147.

22. Ramus J. Alcian blue: a quantitative aqueous assay for algal acids and sulfated polysaccharides. $J$ Phycol 1977; 13: 345-348.

23. Christensen GD, Simpson WA, Younger JJ et al. Adherence of coagulase-negative staphylococci to plastic tissue culture plates: a quantitative model for the adherence of staphylococci to medical devices. J Clin Microbiol 1985; 22 : 996-1006.

24. Bergmeyer HU, Bernt E. Glucose: determination with glucose oxidase and peroxidase. In: Bergmeyer HU (ed) Methods of enzymatic analysis. London, Academic Press. 1974: 1205-1211.

25. Peters G, Schumacher-Perdreau F, Jansen B, Bey M, Pulverer G. Biology of Staphylococcus epidermidis slime. In: Pulverer G, Quie PG, Peters G (eds) Pathogenicity and clinical significance of coagulase-negative staphylococci. Stuttgart, 
Gustav Fischer Verlag. Zentralbl Bakteriol Mikrobiol Hyg (Suppl 16) 1987: 15-32.

26. Ludwicka A, Uhlenbruck G, Peters G et al. Investigation on extracellular slime substance produced by Staphylococcus epidermidis. Zentralbl Bakteriol Mikrobiol Hyg $(A)$ 1984; 258: 256-267.

27. Pfaller M, Davenport D, Bale M, Barrett M, Koontz F, Massanari RM. Development of the quantitative microtest for slime production by coagulase-negative staphylococci. Eur J Clin Microbiol 1989; 7: 30-33.

28. Hogt AH, Dankert J, Feijen J. Adhesion of Staphylococcus epidermidis and Staphylococcus saprophyticus to a hydrophobic biomaterial. J Gen Microbiol 1985; 131 : 2485-2491.

29. Pascual A, Fleer A, Westerdaal NA, Vrhoef J. Modulation of adherence of coagulase-negative staphylococci to Teflon catheters in vitro. Eur J Clin Microbiol 1986; 5: 518-522.

30. Drewry DT, Galbraith L, Wilkinson BJ, Wilkinson SG Staphylococcal slime: a cautionary tale. J Clin Microbiol 1990: 28: 1292-1296.

31. Van Pett K, Schurman DJ, Smith RL. Quantitation of relative distribution of extracellular matrix in Staphylococcus epidermidis biofilm. J Orthop Res 1990; 8: 321-327.

32. Ward JB. Teichoic and teichuronic acids: biosynthesis, assembly, and location. Microbiol Rev 1981; 45: 211-243.

33. Rogers HJ, Perkins HR. 5-Fluorouracil and mucopeptide biosynthesis by Staphylococcus auerus. Biochem J 1960; 77 : 448-459. 